\title{
MECANISMOS DE OTIMIZAÇÃO DE PROTOCOLOS PARA EXTRAÇÃO DE DNA GENÔMICO DE SISAL
}

\author{
$\underline{\text { Pedro Alcantara da Silva Abreu }}{ }^{1}$; Adriana Rodrigues Passos²; Janáira Lopes do Santos \\ Carneiro ${ }^{3}$ \\ 1.Bolsista CNPQ, Graduando em Agronomia, Universidade Estadual de Feira de Santana, e-mail: pedro-804@ hotmail.com \\ 2. Professora Adjunta, Orientadora, Departamento de Ciências Biológicas, Universidade Estadual de Feira de Santana e-mail: \\ adrianarpassos@yahoo.com.br \\ 3. Doutoranda em Recurso Genético Vegetal, Co-orientadora, Departamento de Ciências Biológicas, Universidade Estadual \\ de Feira de Santana, e-mail: janairacarneiro@hotmail.com
}

PALAVRAS-CHAVE: Molecular; Agaveicultura; Biotecnologia.

\section{INTRODUÇÃO}

A Agave Sisalana Perr. (Sisal) pertence à família Agavaceae, e tem como principal produto de interesse comercial suas fibras resistentes extraídas das folhas. O Brasil se destaca na agaveicultura como o maior produtor e exportador mundial da fibra. Segundo a Conab, no ano de 2015, a produção brasileira correspondeu a cerca de 91,1 mil toneladas, $80 \%$ dessa produção foi destinada ao mercado externo (Conab, 2015).

Apesar da importância econômica das fibras de sisal, poucas pesquisas relacionadas a planta foram desenvolvidas, principalmente no que concerne ao melhoramento genético da espécie de modo que quase todo o sisal cultivado mundialmente possui, provavelmente, a mesma constituição genética (Gondin et al., 2009). O melhoramento da espécie via hibridação buscou ampliar a base genética, entretanto, a técnica não produziu resultados satisfatórios. Ademais, progressos em programas de melhoramento de qualquer espécie, no que diz respeito a melhoria de qualquer atributo biológico, tem como base a presença ou criação de variabilidade. Desse modo, torna-se imprescindível conhecer a diversidade genética existente entre e dentre as populações (Stefenon, 2003).

A diversidade genética de uma espécie pode ser detectada utilizando descritores morfológicos e/ou agronômicos. Porém, uma identificação e quantificação mais eficiente e fidedigna desta variabilidade pode ser executada com o auxílio de ferramentas biotecnológicas, destacando os marcadores moleculares. Estes são ferramentas eficazes, pois permitem identificar polimorfismo tendo como base a análise do DNA do vegetal. Para detecção destas informações, faz-se necessário, inicialmente, o estabelecimento de protocolos de extração do DNA genômico. Dentro desta perspectiva, nota-se que a extração de DNA é essencial para o estudo da diversidade genética, pois permite a obtenção de DNA integro e em quantidade satisfatória para amplificações reproduzíveis e confiáveis (Milach, 1998).

A extração de DNA é a primeira etapa para a utilização de genomas em diferentes técnicas da genética molecular, e a sua pureza e qualidade são sempre os pré-requisitos principais (Arbi et al., 2010). O DNA isolado deve estar livre de contaminantes, como polissacarídeos, proteínas e substâncias fenólicas. Nesse sentido, é fundamental seguir todos os procedimentos do protocolo estabelecido (Mazza e Bittencourt, 2000). Portanto, o presente trabalho teve por objetivo otimizar protocolos de extração de DNA de Agave sisalana Perrine apresentando um DNA íntegro e com qualidade satisfatória para estudos de divergência genética da espécie.

\section{METODOLOGIA}

O experimento foi conduzido no Laboratório de Biologia Molecular (LAGEM) da Unidade Experimental Horto Florestal, pertencente à Universidade Estadual de Feira de 
Santana (UEFS). Foram testados dois protocolos de extração de DNA, sendo utilizadas 17 amostras de plantas de sisal oriundas de municípios baianos.

\section{Protocolo 1. Extração do DNA total do tecido foliar por meio da maceração com nitrogênio líquido - Doyle e Doyle (1990)}

Cerca de $300 \mathrm{mg}$ de tecido foliar fresco foram pulverizados em cadinhos de porcelana com nitrogênio líquido e transferidos para tubos de microcentrífuga de $2 \mathrm{~mL}$. Foram adicionados ao material $800 \mu \mathrm{L}$ de tampão de extração $(2 \%$ CTAB; $1,3 \mathrm{M} \mathrm{NaCl} ; 0,2 \%$ 2- $\beta$ mercaptoetanol; $20 \mathrm{mM}$ EDTA; $100 \mathrm{mM}$ Tris-HCl pH 8; 1\% PVP 40). Incubou-se a $70{ }^{\circ} \mathrm{C}$ por 60 minutos, invertendo os tubos, suavemente, a cada 10 minutos. Após deixar esfriar à temperatura ambiente por 5 minutos, foi realizada a desproteinização, adicionando-se $700 \mu \mathrm{L}$ de clorofórmio-álcool isoamílico. Em seguida, as amostras foram agitadas, por suaves inversões, por 10 minutos e centrifugadas a $4{ }^{\circ} \mathrm{C}$, a $18,845 \mathrm{~g}$, por 10 minutos. O sobrenadante de cada amostra foi transferido para tubos de $2 \mathrm{~mL}$, foram adicionados $55 \mu \mathrm{L}$ de CTAB $2 \%$, e o processo de desproteinização foi repetido, acrescentando-se o mesmo volume de clorofórmio-álcool isoamílico. Para a precipitação do DNA, foram adicionados ao sobrenadante $700 \mu \mathrm{L}$ de isopropanol gelado. Os tubos foram mantidos a $-20{ }^{\circ} \mathrm{C}$ por duas horas e, a seguir, centrifugados como anteriormente. $\mathrm{O}$ sobrenadante foi descartado e o precipitado foi lavado duas vezes com etanol $70 \%$ e seco em temperatura ambiente, por aproximadamente 60 minutos. Posteriormente, os ácidos nucleicos totais foram ressuspendidos em $150 \mu \mathrm{L}$ de água contendo RNAse na concentração de $40 \mu \mathrm{g} / \mathrm{mL}$ e colocados em banho-maria, a $37^{\circ} \mathrm{C}$ por 60 minutos, para a completa ressuspensão do DNA e digestão do RNA. Após esse período, o DNA foi novamente precipitado, centrifugado e ressuspendido em $150 \mu \mathrm{L}$ de água como já descrito. A conservação do DNA extraído foi feita a $-20{ }^{\circ} \mathrm{C}$.

\section{Protocolo 2. Extração de DNA total por meio de maceração do tecido foliar diretamente em solução tampão de extração}

Foram macerados 0,3 gramas de tecido vegetal com $3 \mathrm{ml}$ de tampão de extração (CTAB 10\%; $\mathrm{NaCl}$ 5M; Tris-HCl 1M pH 8,0; EDTA 0,5M; Na Sulfite, PVP (Polivinilpirrolidona) e água mili-Q - mantido a $65^{\circ} \mathrm{C}$ ) em um saco plástico. Foram transferidos $2 \mathrm{ml}$ do macerado para tubos de $2 \mathrm{ml}$, sendo misturados por inversão e incubados por 30 minutos em banho-maria a $65^{\circ} \mathrm{C}$, agitando a cada 10 minutos. Ao atingir o tempo, centrifugou-se os tubos a 10000 RPM a temperatura ambiente por 5 minutos, o sobrenadante foi coletado para novos tubos de $2 \mathrm{ml}$. Foram adicionados $800 \mu \mathrm{L}$ de álcool Isoamilico e misturado por inversão. Centrifugou-se por 10 minutos a 10000 RPM a temperatura ambiente. Após coletado o sobrenadante, estes foram transferidos para novos tubos de $1,5 \mathrm{ml}$. Foram adicionados $600 \mu \mathrm{L}$ de álcool Isopropilico (gelado), equivalente a aproximadamente a $2 / 3$ do volume coletado, sendo homogeneizado suavemente e incubado a $-20{ }^{\circ} \mathrm{C}$ por 30 minutos. Foram centrifugados a 10000 RPM a $4{ }^{\circ} \mathrm{C}$ por 10 minutos e o precipitado foi lavado com $500 \mu \mathrm{L}$ de etanol $70 \%$, posteriormente o pellet formado foi deixado para secar. O DNA isolado foi ressuspendido em $30 \mu \mathrm{L}$ de tampão TE (Tris-HCl $10 \mathrm{mM} \mathrm{pH} 8.0$ e EDTA $1 \mathrm{mM}$ ), (RNAse $-1 \mu \mathrm{L}$ amostra) e as amostras foram colocadas na estufa a $37{ }^{\circ} \mathrm{C}$ para a completa solubilização de DNA, por 30 minutos. O DNA concentrado foi conservado a $-20^{\circ} \mathrm{C}$.

\section{Avaliação do DNA obtido:}

Após a extração do material genético, realizou-se a quantificação dos mesmos para ambos os protocolos a fim de verificar a qualidade do DNA. A quantificação foi realizada com uma alíquota total de $6 \mu \mathrm{L}(2 \mu \mathrm{L}$ de DNA, $2 \mu \mathrm{L}$ de gel red e $2 \mu \mathrm{L}$ de corante de 
carregamento) para cada amostra. Estas amostras foram analisadas através de eletroforese em gel de agarose a 1,0\%. A corrida eletroforética foi realizada por 60 minutos a $100 \mathrm{~V}$.

\section{RESULTADOS E DISCUSSÃO}

Foram detectadas diferenças nos dois protocolos utilizados. O protocolo 1 (Doyle e Doyle, 1990) não foi tão eficiente para a extração de DNA de sisal, pois a quantidade e a qualidade do DNA extraído não foi satisfatório, uma vez que este apresentou-se totalmente degradado em todas as amostras (Figura 1).

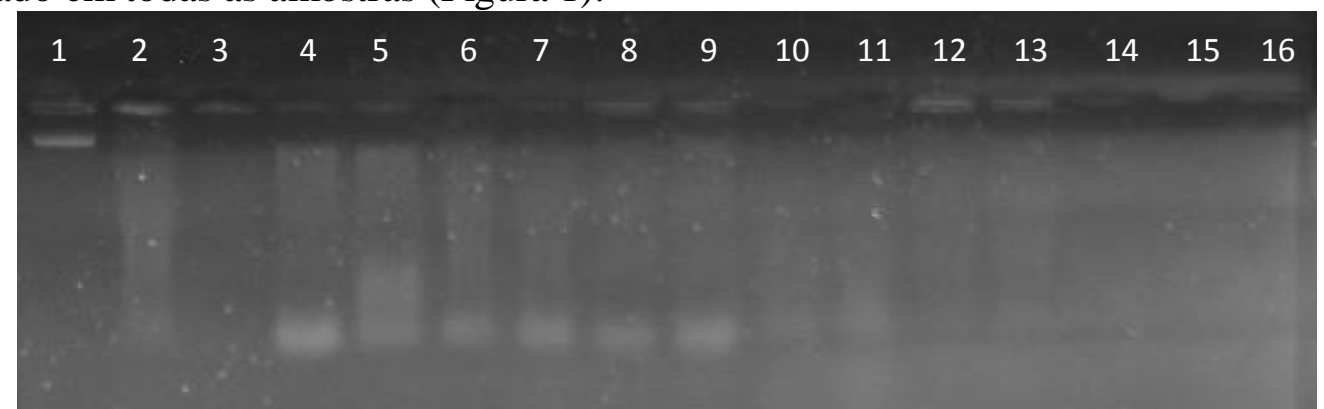

Figura 1: Analise Eletroforética do DNA genômico de sisal utilizando o protocolo de Extração do DNA total do tecido foliar por meio da maceração com nitrogênio líquido - Doyle e Doyle (1990). Amostras aplicadas com volume de 6 $\mu$ L. Amostra 1) $\lambda 10$ ng, 2 a 16) amostras da coleção de sisal da Unidade Experimental Horto Florestal.

O protocolo 2 (Extração de DNA total por meio de maceração do tecido foliar diretamente em solução tampão de extração) possibilitou extrair uma quantidade satisfatória de DNA (Figura 2). Este protocolo decorreu de modificações nas etapas de maceração e na maior porcentagem do CTAB (tampão de extração), facilitando a obtenção de materiais com melhor qualidade e quantidade do que foi encontrado no protocolo anterior, com pequenas parcelas de contaminantes.

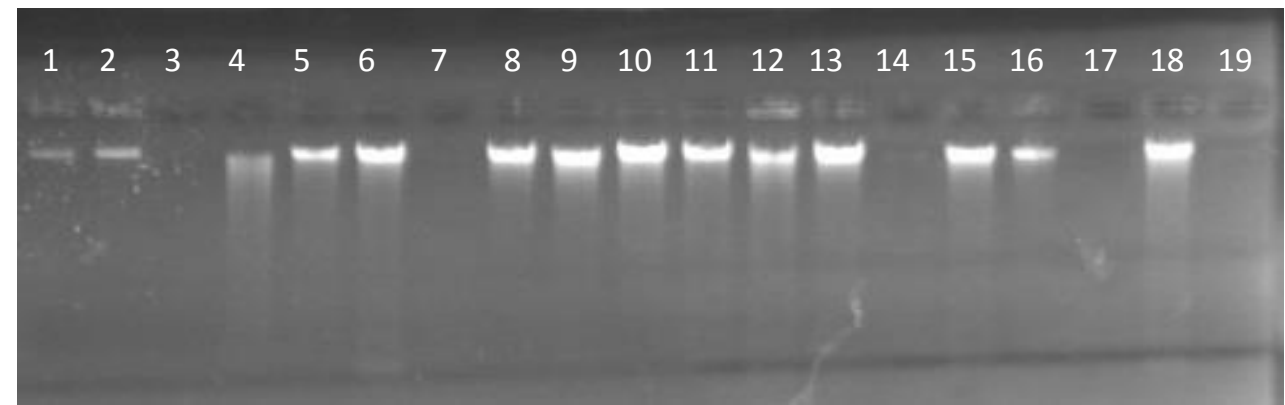

Figura 2: Analise Eletroforética do DNA genômico de sisal utilizando o protocolo de extração de DNA total por meio de maceração do tecido foliar diretamente em solução tampão de extração. Amostras aplicadas com volume de $6 \mu \mathrm{L}$. Amostra 1) $\lambda$ 10 ng, 2) $\lambda 10$ ng, 3 a 17) amostras da coleção de sisal da Unidade Experimental Horto Florestal.

O tampão de extração com o CTAB na concentração de $2 \%$ não foi eficiente para a extração de DNA no protocolo 1 quando comparado com o tampão de extração de concentração de $10 \%$ de CTAB do protocolo 2. Estudos realizados com diferentes concentrações de CTAB no tampão de extração foram avaliados por diferentes autores estudando diversas espécies. Ferreira et al. (2008), ao realizar testes de extração de DNA, verificou que a concentração de CTAB $2 \%$ não foi eficiente para extração de DNA do buriti. Resultados semelhantes foram encontrados por Varella et al. (2013), ao estudarem genótipos de Averrhoa carambola L, testando dois protocolos de extração com CTAB nas concentrações de $2 \%$ e $5 \%$. No presente estudo, destaca-se que a concentração de CTAB de $10 \%$ proporcionou uma maior eficiência no processo de extração de DNA.

\section{CONSIDERAÇÕES FINAIS}

O protocolo 2 obteve maior êxito na extração de DNA de qualidade e em quantidade satisfatória em detrimento dos resultados alcançados pelo protocolo 1. Portanto, o protocolo 
de extração de DNA total por meio de maceração do tecido foliar diretamente em solução tampão de extração, se apresentou o mais eficiente e mais rápido de ser realizado quando comparado ao outro protocolo testado. O uso deste protocolo torna o trabalho mais econômico pela não necessidade do uso do nitrogênio líquido. Sendo assim este protocolo é o mais recomendado para trabalhos com extração de DNA de sisal.

\section{REFERÊNCIAS BIBLIOGRÁFICAS}

ARBI, G.; NACEUR, B.; CHOKRI, M.; MOHAMED, B.; MOHAMED, N. 2010. A simple, rapid and efficient method for the extraction of genomic DNA from Allium roseum L. (Alliaceae). Afr. J. Biotechn., 8(17): 4020-4024.

CONAB. 2015.2 Disponível em: <http://www.conab.gov.br/OlalaCMS/uploads/arquivos/16_02_04_11_15_32_sisal_conjunt ura_especial_retrospectiva_2015-1.pdf $>$. Acessado em: 14 de outubro de 2016.

FERREIRA, M. F. M.; PIMENTA, M. A. S.; JÚNIOR, A. F. M.;TISSOT, S. A.;FERREIRA, P. H. G.;VALÉRIO, H. M.;OlIVEIRA, D. A. 2008. Avaliação da eficiência de três metodologias de extração de DNA do buriti (Mauritia flexuosa Mart.) a partir de folhas e caule. In: IX Simpósio Nacional do Cerrado. Brasília.

GODIN, T. M. S.; SOUSA, L. C. 2009. Caracterização de Frutos e Sementes de Sisal. Circular técnica - EMBRAPA. Campina Grande, PB.

MAZZA, M. C. M.; BITTENCOURT, J. V. M. 2000. Extração de DNA de tecido vegetal de Araucaria angustifolia (Araucariaceae). Boletim de Pesquisa Florestal, Colombo, n. 41, p. $12-$ 17.

MILACH, S.C.K. 1998. Marcadores moleculares em plantas, Porto Alegre:S.C.K. Milach, p.141.

STEFENON, V. M. 2003. Marcadores moleculares no melhoramento genético de araucária. Resvista Biotecnologia Ciência \& Desenvolvimento - Edição n ${ }^{\circ} 31$.

VARELlA, T. L; LAGE, L. A; SilVA, A. B; OLIVEIRA, T. C; CABRAL, J. C; ARELLI, M. A. A; SILVA, M. L; ROSSI, A. A. B. 2013. Padronização de Protocolo de Extração de DNA Genômico de Averrhoa carambola L. e Testes Com Marcadores ISSR. In: $7^{\circ}$ Congresso Brasileiro de Melhoramento de Plantas. Anais... p. 239-249. 